\title{
Characterization of Seasonal Variations in Responsiveness of Pituitary Gland to Different Doses of Gonadotropin Releasing Hormone in Buffalo Cows
}

\author{
R. Medhamurthy*, U.R. Jyotsna, B.S. Kunal, A. Killivalavan, T. Sudeshna and \\ J.P. Ravindra
}

Department of Molecular Reproduction, Development and Genetics (MR, JUR, KBS, KA and ST), Indian

Institute of Science; and National Institute of Animal Nutrition and Physiology (RJP), Bangalore-560012, India

\begin{abstract}
In tropical countries such as India, it has been observed that a number of buffalo cows experience seasonal anestrous during summer months. This might be due to seasonal changes in responsiveness of pituitary gland to gonadotropin releasing hormone $(\mathrm{GnRH})$ and/or decreased hypothalamic $\mathrm{GnRH}$ release. Attempts were made to characterize the responsiveness of pituitary gland to a range of doses $(0.1,1,3,10$ and $33 \mu \mathrm{g})$ of $\mathrm{GnRH}$ in terms of $\mathrm{LH}$ and progesterone $\left(\mathrm{P}_{4}\right)$ secretions during summer (April-May) and rainy (September-November) months. As a part of these studies, a radioimmunoassay method for estimation of circulating LH in buffalo cows was standardized. During summer months, it was observed that in the presence of low circulating $\mathrm{P}_{4}$ levels the minimum dose of $\mathrm{GnRH}$ required for eliciting a significant increase in circulating LH levels was $10 \mu \mathrm{g} / \mathrm{animal}$ that corresponded to a dose of $\sim 28 \mathrm{ng} / \mathrm{kg} \mathrm{BW}$. However, during rainy months, administration of the same dose of $\mathrm{GnRH}$ failed to elicit a response suggesting that the pituitary gland is not responsive to low doses of exogenous $\mathrm{GnRH}$. On the other hand, buffalo cows receiving a dose of $100 \mu \mathrm{g}$ of $\mathrm{GnRH}$ during rainy months elicited a surge-like increase in circulating $\mathrm{LH}$ that peaked at $2 \mathrm{~h}$ and the increase in LH concentrations lasted for nearly $6 \mathrm{~h}$ post $\mathrm{GnRH}$ treatment. The results appear to suggest that during summer months the pituitary gland function is not affected, but there may be lowered hypothalamic GnRH input to the pituitary gland.
\end{abstract}

Keywords: GnRH, LH, FSH, buffalo cows, Holstein-Friesian, rainy season, summer season, hypothalamus, estrous cyclicity, artificial insemination.

\section{INTRODUCTION}

Of the neuroendocrine peptides that play critical role in the control of reproduction in vertebrates, the decapeptide gonadotropin releasing hormone $(\mathrm{GnRH})$ also termed luteinizing hormone releasing hormone (LHRH) for its preferential action on LH secretion, is the key molecule that acts on pituitary gonadotropes to stimulate the secretion of gonadotropins viz., $\mathrm{LH}$ and follicle stimulating hormone (FSH), and these hormones in turn act on the ovary to stimulate its steroidogenesis and gametogenesis. Generally, the ovarian steroids act on the hypothalamus to regulate $\mathrm{GnRH}$ secretion. Also, the ovarian steroids and inhibin act directly on the pituitary gland to modulate the sensitivity of gonadotropes to $\mathrm{GnRH}$. It is now well established that pulsatile secretion of $\mathrm{GnRH}$ is essential for the pulsatile release of LH from pituitary gland into circulation. The pulsatile $\mathrm{LH}$ secretion is used as an indirect measure of hypothalamic GnRH secretion [1]. The pulsatile secretion of $\mathrm{LH}$, and therefore $\mathrm{GnRH}$ secretion, has been shown to fluctuate throughout the reproductive cycle depending on steroid status ranging from one pulse per hour during the

${ }^{*}$ Address corresponding to this author at the Department of Molecular Reproduction, Development and Genetics Indian Institute of Science, Bangalore -560012, India, Tel: +91-80-22932490, Fax: +91-80-23600999; E-mail: rmm@mrdg.iisc.ernet.in follicular phase to one pulse every $3-4 \mathrm{~h}$ or longer during the luteal phase $[2,3]$.

The dose and frequency of exogenous $\mathrm{GnRH}$ administration have marked effects on the pituitary gonadotrophin secretion. Continuous administration of $\mathrm{GnRH}$ leads to desensitization of the pituitary gland responsiveness to $\mathrm{GnRH}$ leading to suppression of $\mathrm{LH}$ secretion, down regulation of $\mathrm{GnRH}$ receptor $(\mathrm{R})$ and decrease in mRNA expressions of GnRHR and $L H \beta$ subunit $[4,5,6]$. Cows experiencing anestrus induced by nutrition deficit or those cows that experience postpartum anestrus reported to have reduced number and amplitude of $\mathrm{LH}$ pulses with low circulating $\mathrm{LH}$ levels [7 - 9]. Thus, different animal models have been employed to evaluate the dose, frequency and duration of exogenous $\mathrm{GnRH}$ required to stimulate pulse secretion of LH [10 - 13]. Studies in anestrus suckled cows indicated that administration of $0.5 \mu \mathrm{g}$ of exogenous $\mathrm{GnRH}$ once every h or $2 \mathrm{~h}$ or $\mathrm{GnRH}$ agonist (15 $\mu \mathrm{g})$ administered as microencapsulated form resulted in increased LH pulse frequency and decreased amplitude [11, 12]. Studies employing nutrition deficit induced anestrus beef cows have shown that administration of $\mathrm{GnRH}$ at hourly intervals resulted in higher LH pulse frequency and the amplitude of $\mathrm{LH}$ pulse increased with increasing doses of $\mathrm{GnRH}$ employed. These studies suggest that 
decreased LH secretion in nutritionally anestrus animals may be due to reduced $\mathrm{GnRH}$ release from the hypothalamus $[6,13]$.

Seasonal variations in environment, nutrition, and management alter incidence of estrous cyclicity in cattle and buffalo cows. It has been documented that increased number of animals exhibited regular estrous cycles and increased conception rate during rainy and winter seasons compared to spring and summer seasons $[14,15]$. Studies on seasonal variations in cyclicity have focussed on the effect of heat stress, temperature and humidity on ovarian function and use of various synchronization protocols to improve conception rates during summer months [16-19]. In cattle, heat stress during summer causes a decrease in amplitude of $\mathrm{LH}$ pulses and the $\mathrm{GnRH}$-induced surge concentrations of $\mathrm{LH}$ and $\mathrm{FSH}$ are lower during summer than in winter [20]. A reduced LH pulse frequency has been observed during the luteal phase as well as reduction in both LH pulse frequency and amplitude during the follicular phase in summer compared to winter in buffalo cows [21]. Also, the lower $\mathrm{LH}$ peak values and circulating $\mathrm{FSH}$ levels were observed in summer months [22, 23]. To date, the responsiveness of the pituitary gland to exogenous $\mathrm{GnRH}$ administration during summer and winter months and the dose of exogenous $\mathrm{GnRH}$ required for eliciting a surge-like increase in circulating LH levels in buffalo cows remains to be established. Thus, the objectives of the present study were to: (i) standardize an assay system to quantitate circulating LH levels in buffalo cows (ii) determine the dose of exogenous $\mathrm{GnRH}$ required to elicit a physiological pulse-like increase in circulating LH levels (iii) characterize and compare the response of the pituitary gland to a range of doses of exogenous $\mathrm{GnRH}$ during summer and rainy months, and (iv) to determine the dose of exogenous $\mathrm{GnRH}$ required to elicit a surge-like increase in circulating LH levels leading to ovulation during rainy months (breeding season) in buffalo cows.

\section{MATERIALS AND METHODS}

\section{Reagents}

$\mathrm{GnRH}$ (LHRH) was procured from Sigma-Aldrich, Bangalore, India. Anti-bovine $\mathrm{LH}$ antiserum (Lot\# USDA-309-684P) and iodination grade bovine $\mathrm{LH}$ (AFP11743B) were procured from Dr. A.F. Parlow, National Hormone and Peptide Program (NHPP), Harbor-UCLA Research and Education Institute, CA, USA. All other reagents were purchased from SigmaAldrich, Bangalore, India.

\section{Analysis of Reproductive Cyclicity Data Throughout the Year in Buffalo Cow}

With a view to determine whether fewer animals exhibited estrous cycles during summer months, we analysed information of reproductive cyclicity data such as number of buffalo cows reporting every month for artificial insemination service from one of the veterinary service centres in the state of Karnataka, India. The cyclicity data available for analysis were for years 2003-2005. For comparison purpose, we also analysed monthly cyclicity data information for Holstein-Friesian cross bred dairy cows for years 2003 and 2004. The data is presented as total number of buffalo cows/cross bred cows reporting for Al service. From the cyclicity data, whether the same animal was reported for Al more than once was not determined.

\section{Effect of Different Doses of GnRH Treatment on LH Secretion During Summer and Rainy Months}

Six non lactating buffalo cows were used for the studies. The experimental protocol for $\mathrm{GnRH}$ challenge experiment involved intravenous administration of different doses of $\mathrm{GnRH}$ viz., 0.1, 1, 3, 10 and $33 \mu \mathrm{g}$ to buffalo cows. Blood samples were collected immediately before, 30, 60, 120, 180 and 240 min after intravenous injection of $\mathrm{GnRH}$. Based on the body weights, the doses of $\mathrm{GnRH}$ corresponded to $\sim 0.28$, 2.8, 8.4, 28 and $92.4 \mathrm{ng} / \mathrm{kg} \mathrm{BW}$ for $0.1,1,3,10$ and 33 $\mu \mathrm{g}$ of $\mathrm{GnRH}$ employed. The same sets of animals were used for studying the response to different doses of $\mathrm{GnRH}$ during summer and rainy months. The experiments were carried out in the year 2007. The temperature during April and May months ranged from a minimum of $18.2^{\circ} \mathrm{C}$ (April)/ $20^{\circ} \mathrm{C}$ (May) to maximum of $36.1^{\circ} \mathrm{C}$ (April)/ $35.6^{\circ} \mathrm{C}$ (May) and the temperatures were $19^{\circ} \mathrm{C} / 31^{\circ} \mathrm{C}, \quad 18^{\circ} \mathrm{C} / 32^{\circ} \mathrm{C}$ and $13^{\circ} \mathrm{C} / 29^{\circ} \mathrm{C}$ for September, October and November months, respectively.

\section{Experiments During Summer Months}

During summer months of April and May 2007, buffalo cows were monitored for circulating $\mathrm{P}_{4}$ levels over a period of 3 weeks to assess the ovarian function. After confirming for presence of low $\mathrm{P}_{4}$ levels $(<1 \mathrm{ng} / \mathrm{ml} 3$ weeks before and at the time of start of the experiment) indicative of absence of luteal function, the animals were assigned to receive different doses of $\mathrm{GnRH}$ in random order. Doses of $\mathrm{GnRH}$ administered with the number $(n)$ of animals receiving each dose of $\mathrm{GnRH}$ indicated in the parenthesis are as follows: 0.1 $(n=4), 1(n=3), 3(n=2), 10(n=5)$ and $33(n=1) \mu g$ of 
$\mathrm{GnRH}$. An interval of at least one week separated between each dose tested within the animal. Blood samples collected at different time intervals were assayed for $\mathrm{P}_{4}$ and $\mathrm{LH}$.

\section{Experiments During Rainy Months}

During rainy months of August, September and October 2007, buffalo cows were monitored for circulating $\mathrm{P}_{4}$ levels over a period of 3 weeks to assess the ovarian function. After confirming for presence of high circulating $\mathrm{P}_{4}$ levels $(\geq 1 \mathrm{ng} / \mathrm{ml})$ indicative of luteal activity, the animals were assigned to receive different doses of $\mathrm{GnRH}$ in random order. Doses of $\mathrm{GnRH}$ administered intravenously with the number of buffalo cows receiving each dose of $\mathrm{GnRH}$ indicated in the parenthesis, are as follows: $0.1(n=3), 1(n=3)$ and 10 $(n=5) \mu \mathrm{g}$ of $\mathrm{GnRH}$. An interval of at least one week separated between the each dose tested within the animal. Blood samples were collected at different time intervals were assayed for $\mathrm{P}_{4}$ and $\mathrm{LH}$.

\section{Effect of a Large Bolus of GnRH on LH Secretion in Buffalo Cows}

In cattle, it is well established that administration of a bolus of $\mathrm{GnRH}$ during the preovulatory period results in surge-like release of $\mathrm{LH}$ and FSH [24]. In this experiment, effect of intramuscular injection of $100 \mu \mathrm{g}$ of $\mathrm{GnRH}$ on $\mathrm{LH}$ secretion was examined in buffalo cows. After confirming for presence of high circulating $\mathrm{P}_{4}$ levels and thus functional corpus luteum, three animals received intramuscular injection of $100 \mu \mathrm{g}$ of $\mathrm{GnRH}$, and blood samples were collected immediately before and at hourly intervals for $6 \mathrm{~h}$ post $\mathrm{GnRH}$ injection.

\section{Hormone Assays}

Serum $\mathrm{P}_{4}$ concentrations were determined by specific radioimmunoassay as reported previously [25].

\section{Radioimmunoassay (RIA) for LH}

Serum LH concentration was determined by employing bovine LH assay reagents. The protocol for LH assay standardized in the laboratory is outlined below. The composition of RIA buffer in which hormone and antiserum were diluted contained $0.05 \mathrm{M}$ sodium dihydrogen phosphate (phosphate buffer), $4.5 \mathrm{mM}$ EDTA and $150 \mathrm{mM} \mathrm{NaCl}$ and $0.1 \%$ of gelatin. Bovine LH was radio-iodinated according to Sairam et al., [26] with some modifications in the present study. To $5 \mu \mathrm{g}$ of the hormone, $0.5 \mathrm{mCi}^{125} \mathrm{I}$ in $20 \mu$ ldistilled water and $25 \mu \mathrm{l}$ of $0.05 \mathrm{M}$ phosphate buffer were added. After gentle mixing and incubating for $50 \mathrm{sec}, 10 \mu \mathrm{l}$ of Chloramine- $\mathrm{T}(15 \mu \mathrm{g})$ solution in $0.05 \mathrm{M}$ phosphate buffer was added and the reaction was terminated by adding $30 \mu \mathrm{l}$ of sodium metabisulphite $(45 \mu \mathrm{g})$ solution. The iodinated hormone was separated on Sephadex G-25 (coarse) column. Serial dilutions of iodination grade bovine $\mathrm{LH}$ antigen was prepared in $0.05 \mathrm{M}$ phosphate buffer containing $0.9 \% \mathrm{NaCl}$ and the concentration range of bLH used to prepare the standard curve was: $0.01,0.02,0.04,0.08,0.1,0.2$, $0.4,0.8,1.0,2.0 \mathrm{ng} /$ tube. Anti-bovine $\mathrm{LH}$ antiserum diluted $(1: 30,000)$ in RIA buffer containing 1:100 normal rabbit serum was added to each tube. The assay contained tubes for measuring non-specific binding (NSB; RIA buffer + labeled LH) and maximum binding ( $\mathrm{B}_{0}$; contained RIA buffer + antiserum + labeled LH). To the NSB tubes, $100 \mu \mathrm{l}$ of NRS-EDTA-PBS was added and for rest of the tubes $100 \mu \mathrm{l}$ of 1:30,000 anti-bovine $\mathrm{LH}$ antiserum, $100 \mu \mathrm{l}$ of standard or sample was added to the respective tubes and the total volume was made up to $400 \mu \mathrm{l}$ in each tube by addition of $0.05 \mathrm{M} \mathrm{RIA}$ buffer. The tubes were vortexed and incubated at room temperature for 2 days. Later, $50 \mu$ of iodinated bovine LH containing $20,000 \mathrm{cpm}$ was added to each tube, vortexed and incubated for $24 \mathrm{~h}$ at room temperature and at the end of the incubation, $100 \mu$ of $1: 2$ diluted rabbit double antibody was added, vortexed and incubated further for $24 \mathrm{~h}$. The assay was terminated by adding $3 \mathrm{ml}$ ice-cold 1X PBS. The tubes were centrifuged at $2600 \mathrm{~g}$ at $4^{\circ} \mathrm{C}$ for $30 \mathrm{~min}$. The supernatant was decanted and the pellet counted in gamma counter (Wallac Wizard ${ }^{\mathrm{TM}} 1470$ automatic, Perkin Elmer, Massachusetts, USA). The standard curve was constructed using cpm obtained for different hormone concentrations. The sensitivity of the assay was $0.02 \mathrm{ng} / \mathrm{tube}$, and inter- and intra-assay coefficients of variation were $<10 \%$.

\section{Statistical Analysis}

Data was expressed as mean \pm SEM. LH data analyzed by ANOVA followed by Neuman-Keuls multiple comparison test (PRISM graph pad v2, Graphpad software, Inc. USA). A 'P'value of $<0.05$ was considered statistically significant.

\section{RESULTS}

\section{Analysis of reproductive cyclicity data}

Figure 1 shows number of animals reported for $\mathrm{Al}$ service for buffalo cows (Surthi breed) and HolsteinFriesian cross bred cows. In buffalo cows, as can be seen from the Figure 1, the number of animals (also 


\section{Surti}

\section{3}
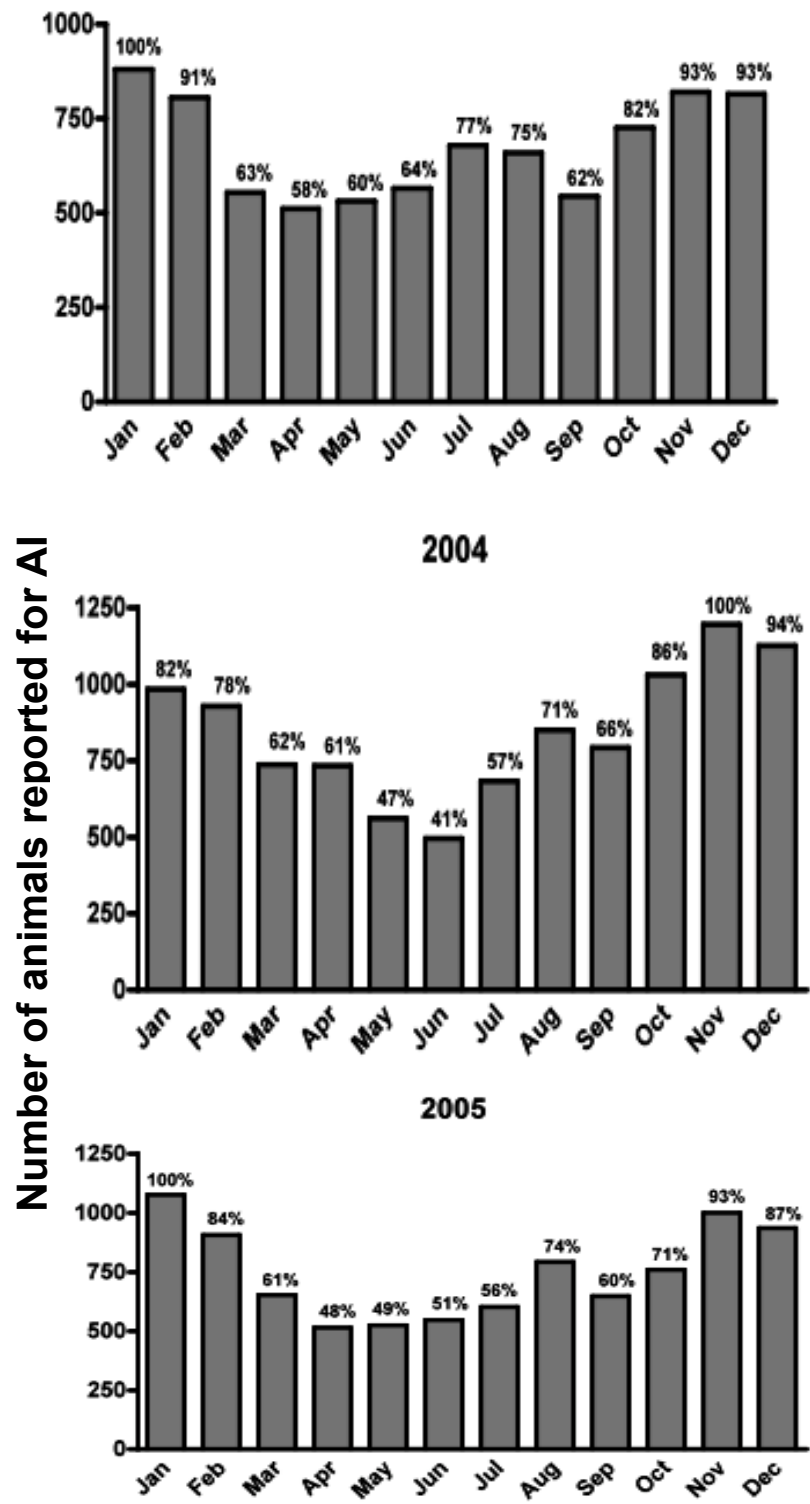

\section{Holstein-Friesian}

2003

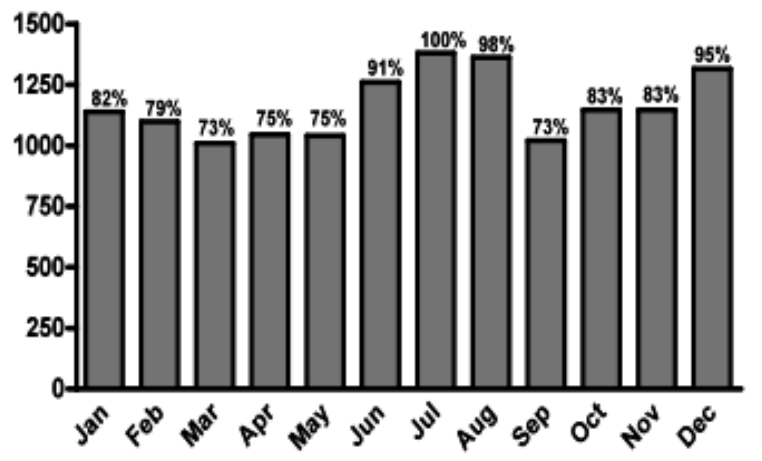

2004

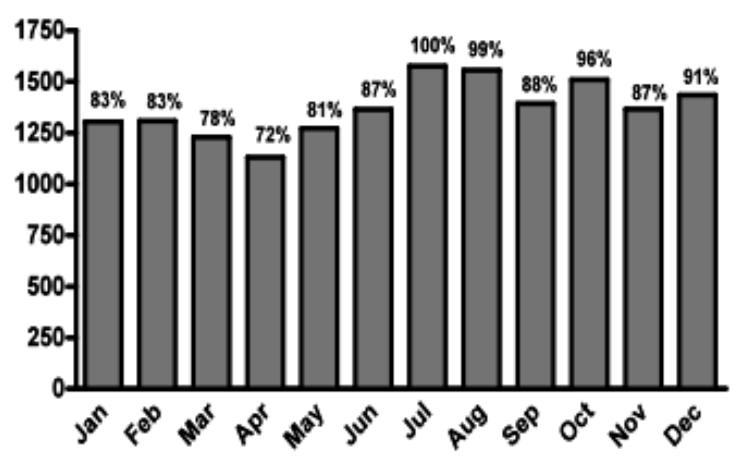

Figure 1: Bar diagram representation of number of buffaloes (Surti breed) and Holstein-Friesian cross bred cows reporting for Al service every month in the year 2003-2005 in one of the veterinary Al service centres in Karnataka, India. In each year, the maximum number of animals reporting for $\mathrm{Al}$ in a given month was set as $100 \%$ and the number of animals reporting for other months was expressed in relation to $100 \%$. The calculated percent of animals reporting for Al for each month is shown on individual bar graph.

represented as $\%$ of animals) reported for $\mathrm{Al}$ are lower during summer months compared to rainy and winter months.

\section{Characterization of Pituitary Response to Exogenous GnRH Treatment During Different Seasons}

\section{a) Summer Months}

Circulating $\mathrm{P}_{4}$ levels were monitored in buffalo cows for 3 weeks prior to the beginning of $\mathrm{GnRH}$ challenge experiment and immediately before administration of $\mathrm{GnRH}$. Serum $\mathrm{P}_{4}$ levels were $0.66 \pm 0.3 \mathrm{ng} / \mathrm{ml}$ and 0.36 $\pm 0.1 \mathrm{ng} / \mathrm{ml}$ three weeks prior to and at the start of $\mathrm{GnRH}$ challenge experiment, respectively in buffalo cows. The circulating levels of $\mathrm{LH}$ in response to $\mathrm{GnRH}$ challenge experiment in buffalo cows is illustrated in Figure 2. Administration of $\mathrm{GnRH}$ at doses of $0.1,1$ and $3 \mu \mathrm{g}$ (data not shown) did not result in a significant increase in circulating LH over basal levels (Figure 2, left panel). However, administration of $10 \mu \mathrm{g}$ of $\mathrm{GnRH}$ 
Summer
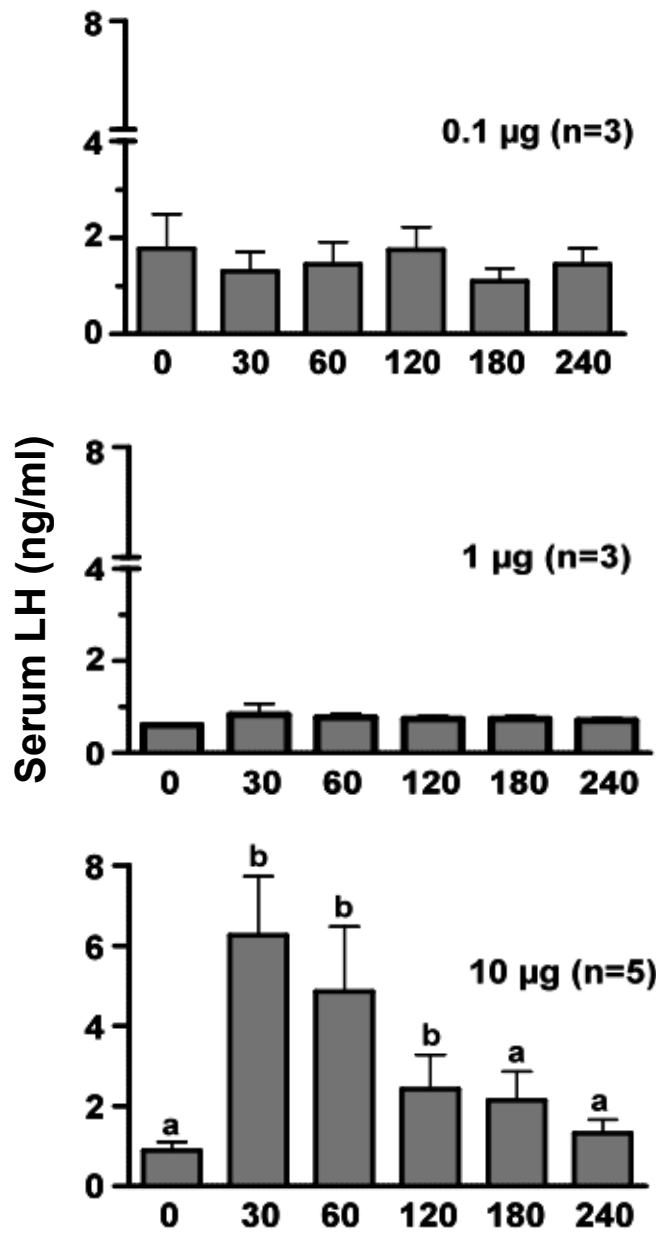

Rainy months
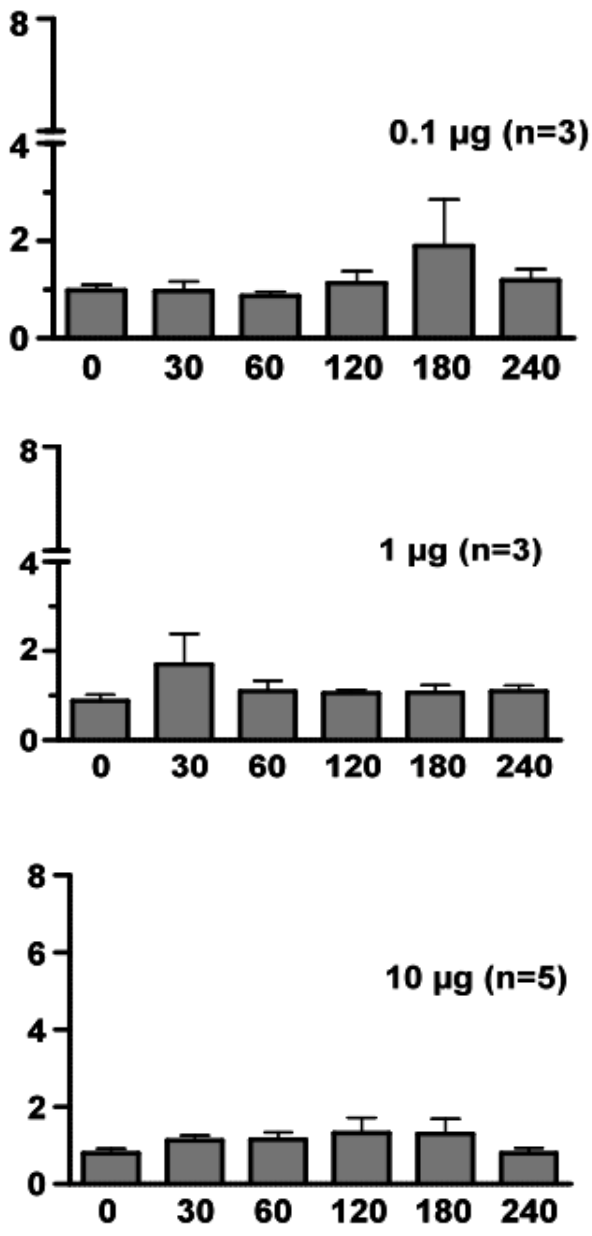

Time (min) post GnRH injection

Figure 2: Mean $( \pm$ SEM) of serum concentrations of $\mathrm{LH}$ in buffalo cows before and after administration of different doses of $\mathrm{GnRH}$.

resulted in a significant increase in circulating concentration of $\mathrm{LH}$ from basal levels of $0.88 \pm 0.23$ $\mathrm{ng} / \mathrm{ml}$ to $6.27 \pm 1.8 \mathrm{ng} / \mathrm{ml}$ at $30 \mathrm{~min}$ post $\mathrm{GnRH}$ treatment. This was followed by a gradual decrease at later time points to reach basal levels by $240 \mathrm{~min}$. Administration of $33 \mu \mathrm{g}$ of $\mathrm{GnRH}$ resulted in a further increase in circulating $\mathrm{LH}$ levels from basal levels of $0.46 \mathrm{ng} / \mathrm{ml}$ up to $10 \mathrm{ng} / \mathrm{ml}$ by $30 \mathrm{~min}$ followed by a gradual decline and the circulating $\mathrm{LH}$ level remained above the pre-treatment level.

The dose response curve for $\mathrm{GnRH}$ vs fold increase in circulating $\mathrm{LH}$ levels demonstrated that a higher dose of $\mathrm{GnRH}$ was required to reach plateau in terms of increase in circulating LH levels (Figure 3 ).

\section{b) Rainy Months}

Concentrations of $\mathrm{P}_{4}$ in circulation were monitored and the $\mathrm{P}_{4}$ levels were $1.2 \pm 0.4 \mathrm{ng} / \mathrm{ml}$ and $1.8 \pm 0.2$ $\mathrm{ng} / \mathrm{ml}$ in buffalo cows for 3 weeks prior to and during the $\mathrm{GnRH}$ challenge experiment. Administration of $\mathrm{GnRH}$ at doses of $0.1,1$ and $10 \mu \mathrm{g}$ did not result in a significant increase in circulating $\mathrm{LH}$ over the basal levels (Figure 2, right panel).

\section{Circulatory LH Secretion in Response to Large Bolus of GnRH Treatment}

Administration of $100 \mu \mathrm{g}$ dose of $\mathrm{GnRH}$ resulted in increased circulating $\mathrm{LH}$ from basal levels of $0.83 \pm$ 0.27 to $15.3 \pm 1.6 \mathrm{ng} / \mathrm{ml}$ by $1 \mathrm{~h}$, and the levels were $27.6 \pm 5.3 \mathrm{ng} / \mathrm{ml}$ at $2 \mathrm{~h}$ post $\mathrm{GnRH}$ administration followed by a gradual decrease by $4 \mathrm{~h}$ post $\mathrm{GnRH}$ administration (Figure 4).

\section{DISCUSSION}

It has been well documented that during spring and summer months, fewer number of animals return to 


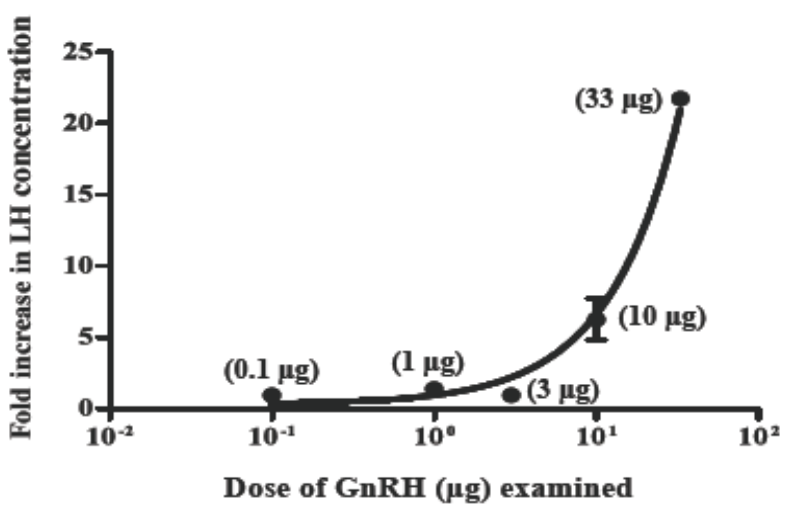

Figure 3: Effects of different doses of GnRH on LH secretion in buffalo cows during summer.

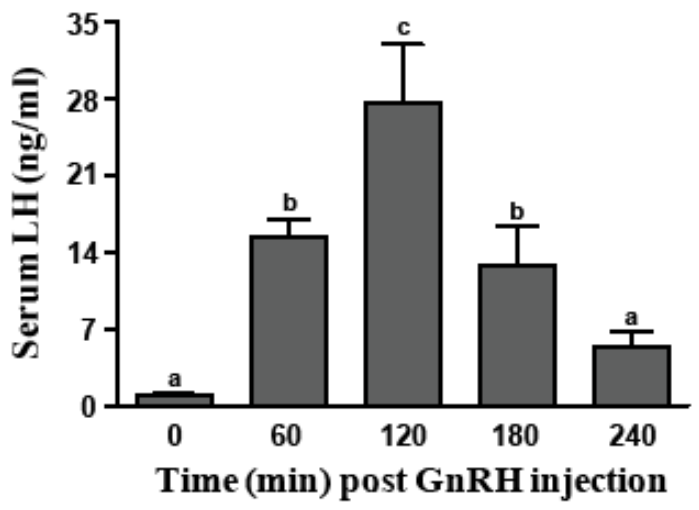

Figure 4: Mean ( \pm SEM) of serum concentrations of $\mathrm{LH}$ in buffalo cows before and after administration of $100 \mu \mathrm{g}$ $\mathrm{GnRH}$.

estrus compared to winter and rainy seasons in cattle and buffalo cows [14, 27, 28]. The seasonal variations in the reproductive cyclicity are most likely due to change in the activity of hypothalamo-pituitary-ovarian axis that controls normal reproductive cyclicity in mammals. Pulsatile GnRH stimulation of pituitary gonadotropes is required for and reflected in the pulsatile LH secretion [1]. However, the feedback regulation at the pituitary gland by steroids can modify or eliminate the responsiveness of the pituitary to $\mathrm{GnRH}$ pulses [1]. In the absence of such feedback effects, when the frequency and amplitude of $\mathrm{GnRH}$ pulse are fixed, the amplitude of an $\mathrm{LH}$ pulse is the direct measure of the releasable stores of $\mathrm{LH}$ in gonadotropes [29]. Due to difficulties in accessing biological samples for direct $\mathrm{GnRH}$ measurement, estimation of LH in circulation is regarded as bioassay for hypothamalic $\mathrm{GnRH}$ secretion. Exogenous administration of $\mathrm{GnRH}$ has been used in various animal models and human subjects to evaluate the responsiveness of the pituitary gland and regulation of gonadotropin secretion [6, 10-13, 30, 31]. In order to delineate the underlying causes for seasonal variations in the cyclicity in buffalo cows, in the present study we attempted to evaluate the response of the pituitary gland to a single injection of a range of doses of $\mathrm{GnRH}$ during summer and rainy months.

During summer, the minimum dose of $\mathrm{GnRH}$ required for eliciting a response as evident from increased circulating LH levels was $28 \mathrm{ng} / \mathrm{kg}$ BW (10 $\mu \mathrm{g}$ of $\mathrm{GnRH}$ bolus) and administration of this dose elicited a response similar to a physiological LH pulse in duration and amplitude (unpublished data). The response of the buffalo cows to 28 and $92.4 \mathrm{ng} / \mathrm{kg} \mathrm{BW}$ dose of $\mathrm{GnRH}$ was similar to the response reported previously in prepubertal heifers administered as small repeated doses or with a bolus of $\mathrm{GnRH}[32,33]$. In the experiments conducted in the same buffalo cows during winter season however, no response to $\mathrm{GnRH}$ administration to $0.1,1$ and $10 \mu \mathrm{g}$ of $\mathrm{GnRH}$ doses examined. On the other hand, administration of a large bolus of $\mathrm{GnRH}$ (i.e. $100 \mu \mathrm{g}$ ) elicited a surge-like increase in circulating $\mathrm{LH}$ levels similar to the response observed in cattle [24, 34]. Also, we have recently reported that $100 \mu \mathrm{g}$ of $\mathrm{GnRH}$ was sufficient to induce gonadotropin surge and ovulation in buffalo cows [35]. The variation in the pituitary responsivity to exogenous $\mathrm{GnRH}$ administration observed during the two seasons could be due to differences in the circulating steroid milieu. It has been reported that increased circulating $\mathrm{P}_{4}$ levels decreases the number of $\mathrm{GnRH}$ pulses [36] and moreover, $\mathrm{P}_{4}$ is also known to decrease the transcription and the number of $\mathrm{GnRH}$ receptors on gonadotropes in cultured pituitary cells and the observation of lowest number of $\mathrm{GnRH}$ receptors in the pituitary membranes during the luteal phase of estrous cycle $[37,38]$. Studies in ewes have established that $P_{4}$ inhibits the $\mathrm{GnRH}$ receptor expression by reducing the frequency of $\mathrm{GnRH}$ pulses [39]. It should be pointed out that the available pituitary LH stores also contribute to the magnitude of response observed during the two seasons. It is entirely possible that more releasable pool of LH was available during summer compared to rainy months.

Estradiol $\left(E_{2}\right)$ is believed to be the primary factor responsible for modulating the gonadotrope responsiveness to $\mathrm{GnRH}$ especially around the time of occurrence of preovulatory gonadotropin surge. During the preovulatory period, $E_{2}$ causes increase in the number of $\mathrm{GnRH}$ receptors on membranes of pituitary gonadotropes and stimulates a sustained increase in $\mathrm{GnRH}$ release from hypothalamus causing $\mathrm{LH}$ surge and $\mathrm{P}_{4}$ can act on the $\mathrm{E}_{2}$ responsive cells in 
hypothalamus to block the occurrence of gonadotropin surge [40, 41]. Studies on ovariectomized cattle and pony mares demonstrate that $E_{2}$ treatment is associated with an increase in pituitary responsively and circulatory LH levels [42, 43]. In ewes, basal levels of $\mathrm{LH}$ in the circulation are high during the follicular phase of the estrous cycle and $E_{2}$ treatment of anterior pituitary cells obtained from anestrus ewes caused an increase in LH secretion [38]. Studies in cattle by Day et al. [44] and Stumpf et al. [45] demonstrated that effects of $E_{2}$ in regulating pituitary LH secretion was independent of the seasons, however, the effects of heat stress on tonic $\mathrm{LH}$ as well as on $\mathrm{GnRH}$-induced preovulatory surge concentrations were found to be dependent on the concentration of $E_{2}$ in plasma [46]. However, in the present study, the circulating $E_{2}$ levels during the $\mathrm{GnRH}$ challenge experiments were not monitored.

In response to a $100 \mu \mathrm{g}$ dose of $\mathrm{GnRH}$, a surge-like increase in the circulating $\mathrm{LH}$ levels was observed. Similar results in cows were observed by previous studies, where higher doses of $\mathrm{GnRH}$ up to $1500 \mu \mathrm{g}$ have been administered [47] or similar doses of $\mathrm{GnRH}$ were administered during the periovulatory period [24, 34].

In summary, in the present study attempts were made to evaluate the seasonal changes in the pituitary responsiveness in buffalo cows. A dose of $10 \mu \mathrm{g}$ of $\mathrm{GnRH}$ was sufficient to induce a pulse-like increase in circulating $\mathrm{LH}$ levels during summer, in the presence of lower circulating $\mathrm{P}_{4}$ levels while, during rainy months, no increase in the circulating $\mathrm{LH}$ levels were observed in response to $10 \mu \mathrm{g}$ or lower doses of $\mathrm{GnRH}$ indicating decreased responsiveness of pituitary in the presence of high circulating $\mathrm{P}_{4}$ levels. Also, the dose of $\mathrm{GnRH}$ required for eliciting a surge-like increase in $\mathrm{LH}$ secretion was determined.

\section{ACKNOWLEDGEMENTS}

This work was supported by NFBSRA/PCN/AP07/2006-07 and NAIP-ICAR (NAIP/C4/C1056), Indian Council of Agricultural Research, India.

\section{REFERENCES}

[1] Clarke IJ. Two decades of measuring GnRH secretion. Reprod Suppl 2002; 59: 1-13.

[2] Rahe $\mathrm{CH}$, Owens RE, Fleeger JL, Newton HJ, Harms PG. Pattern of plasma luteinizing. Endocrinology 1980; 107: 498-503.

http://dx.doi.org/10.1210/endo-107-2-498

[3] Walters DL, Schallenberger E. Pulsatile secretion of gonadotrophins. J Reprod Fertil 1984; 71: 503-12. http://dx.doi.org/10.1530/jrf.0.0710503
Peters AR, Pimentel MG, Lamming GE. Hormone responses. J Reprod Fertil 1985; 75: 557-65.

http://dx.doi.org/10.1530/jrf.0.0750557

[5] Lamming GE, McLeod BJ. Continuous infusion of GnRH. J Reprod Fertil 1988; 82: 237-46.

http://dx.doi.org/10.1530/jrf.0.0820237

[6] Vizcarra JA, Wettemann RP, Braden TD, Turzillo AM, Nett TM. Effect of gonadotropin-releasing hormone. Endocrinology 1997; 138: 594-601.

http://dx.doi.org/10.1210/en.138.2.594

[7] Peters AR, Lamming GE, Fisher MW. A comparison of plasma LH. J Reprod Fertil 1981; 62: 567-73. http://dx.doi.org/10.1530/jrf.0.0620567

[8] Williams GL, Kotwica J, Slanger WD, Olson DK, Tilton JE, Johnson LJ. Effect of suckling on pituitary responsiveness. $J$ Anim Sci 1982; 54: 594-02.

[9] Richards MW, Wettemann RP, Schoenemann HM. Nutritional anestrus. J Anim Sci 1989; 67: 1520-26.

[10] Riley GM, Peters AR, Lamming GE. Induction of pulsatile LH release. J Reprod Fertil 1981; 63: 559-65. http://dx.doi.org/10.1530/jrf.0.0630559

[11] Spicer LJ, Convey EM, Tucker HA, Echternkamp SE. Effects of intermittent injections of LHRH. J Anim Sci 1986; 62: 131723.

[12] Roberge S, Schramm RD, Schally AV, Reeves JJ. Reduced postpartum anestrus. J Anim Sci 1992; 70: 3825-30.

[13] Vizcarra JA, Wettemann RP, Morgan GL. Influence of dose, frequency, and duration of infused gonadotropin-releasing hormone. Domest Anim Endocrinol 1999; 16: 171-81. http://dx.doi.org/10.1016/S0739-7240(99)00007-7

[14] Gwazdauskas FC. Effects of climate. J Dairy Sci 1985; 68: 1568-78.

http://dx.doi.org/10.3168/jds.S0022-0302(85)80995-4

[15] Singh J, Nanda AS, Adams GP. The reproductive pattern. Anim Reprod Sci 2000; 60-61: 593-604.

http://dx.doi.org/10.1016/S0378-4320(00)00109-3

[16] Wolfenson D, Thatcher WW, Badinga L, et al. Effect of heat stress. Biol Reprod 1995; 52: 1106-13.

http://dx.doi.org/10.1095/biolreprod52.5.1106

[17] Wilson SJ, Kirby CJ, Koenigsfeld AT, Keisler DH, Lucy MC Effects of controlled heat. J Dairy Sci 1998; 81: 2132-8. http://dx.doi.org/10.3168/jds.S0022-0302(98)75789-3

[18] Delasota RL, Burke JM, Risco CA, Moreira F, DeLorenzo MA, Thatcher WW. Evaluation of timed insemination. Theriogenology 1998; 49: 761-70.

[19] Ahuja C, Montiel F, Canseco R, Silva E, Mapes G. Pregnancy rate following GnRH. Anim Reprod Sci 2005; 87: 203-13.

http://dx.doi.org/10.1016/j.anireprosci.2004.12.002

[20] Gilad E, Meidan R, Berman A, Graber Y, Wolfenson D. Effect of heat stress. J Reprod Fertil 1993; 99: 315-21. http://dx.doi.org/10.1530/jrf.0.0990315

[21] Aboul-Ela MB, Barkawi AH. Pulsatile secretion of $\mathrm{LH}$ in cycling buffalo heifers as affected by season and stage of oestrous cycle. Proceedings of the 11th International Congress on Animal Reproduction and Artificial Insemination; 1988: Dublin; pp. 26-30.

[22] Janakiraman K, Desai MC, Amin DR, Sheth AR, Moodbidri $\mathrm{SB}$, Wadadekar KB. Serum gonadotropin levels. Indian J Anim Sci 1980; 50: 601-6.

[23] Razdan MN, Kaker ML, Galhotra MM. Serum FSH levels.Theriogenology 1982; 17: 175-81. http://dx.doi.org/10.1016/0093-691X(82)90077-2

[24] Komar CM, Berndtson AK, Evans AC, Fortune JE. Decline in circulating estradiol. Biol Reprod 2001; 64: 1797-05. http://dx.doi.org/10.1095/biolreprod64.6.1797 
[25] Selvaraj N, Medhamurthy R, Ramachandra SG, Sairam MR, Moudgal NR. Assessment of luteal rescue. J Biosci 1996; 21: 497-500. http://dx.doi.org/10.1007/BF02703214

[26] Sairam MR, Ranganathan MR, Ramasharma K. Binding of an inhibin-like protein. Mol Cell Endocrinol 1981; 22:251-64. http://dx.doi.org/10.1016/0303-7207(81)90095-2

[27] Fuquay JW. Heat stress. J Anim Sci 1981; 52: 164-74.

[28] Francos G, Mayer E. Observations on some environmental. Theriogenology 1983; 19: 625-34. http://dx.doi.org/10.1016/0093-691X(83)90103-6

[29] Clarke IJ, Cummins JT. GnRH pulse frequency. J Reprod Fertil 1985; 73: 425-31. http://dx.doi.org/10.1530/jrf.0.0730425

[30] Edwards S, Roche JF, Niswender GD. Response of suckling beef cows. J Reprod Fertil 1983; 69: 65-72. http://dx.doi.org/10.1530/jrf.0.0690065

[31] Dafopoulos KC, Kotsovassilis CP, Milingos SD, et al. FSH and LH. Clin Endocrinol (Oxf) 2004; 60: 120-4. http://dx.doi.org/10.1111/j.1365-2265.2004.01948.x

[32] Barnes MA, Bierley ST, Halman RD, Henricks DM. Follicle stimulating hormone. Biol Reprod 1980; 22: 459-65. http://dx.doi.org/10.1095/biolreprod22.3.459

[33] McLeod BJ, Haresign W, Peters AR, Lamming GE. Plasma LH and FSH concentrations. J Reprod Fertil 1984; 70: 13744

http://dx.doi.org/10.1530/jrf.0.0700137

[34] Haughian JM, Ginther OJ, Kot K, Wiltbank MC. Relationships between FSH patterns. Reproduction 2004; 127: 23-33. http://dx.doi.org/10.1530/rep.1.00030

[35] Rao JU, Kunal B. Shah, Jayaram Puttaiah, Medhamurthy Rudraiah. Gene expression. PLoS One 2011; 6(6): e20754. http://dx.doi.org/10.1371/journal.pone.0020754

[36] Karsch FJ, Cummins JT, Thomas GB, Clarke IJ. Steroid feedback. Biol Reprod 1987; 36:1207-18. http://dx.doi.org/10.1095/biolreprod36.5.1207
[37] Brooks J, McNeilly AS. Regulation of gonadotrophin. J Endocrinol 1994; 143: 175-82.

http://dx.doi.org/10.1677/joe.0.1430175

[38] Turzillo AM, Clapper JA, Moss GE, Nett TM. Regulation of ovine GnRH. J Reprod Fertil 1998; 113: 251-6.

http://dx.doi.org/10.1530/jrf.0.1130251

[39] Turzillo AM, Juengel JL, Nett TM. Pulsatile gonadotropinreleasing hormone. Biol Reprod 1995; 53: 418-23. http://dx.doi.org/10.1095/biolreprod53.2.418

[40] Schoenemann HM, Humphrey WD, Crowder ME, Nett TM, Reeves JJ. Pituitary luteinizing hormone. Biol Reprod 1985; 32: $574-83$.

http://dx.doi.org/10.1095/biolreprod32.3.574

[41] Richter TA, Robinson JE, Lozano JM, Evans NP. Progesterone can block. J Neuroendocrinol 2005; 17: 161-9. http://dx.doi.org/10.1111/j.1365-2826.2005.01287.x

[42] Garza F, Jr., Thompson DL, Jr., St George RL, French DD. Androgen and estradiol. J Anim Sci 1986; 62: 1654-9.

[43] Sharp DC, Grubaugh WR, Weithenauer J, Davis SD, Wilcox CJ. Effects of steroid administration. Biol Reprod 1991; 44: 983-90.

http://dx.doi.org/10.1095/biolreprod44.6.983

[44] Day ML, Imakawa K, Pennel PL, et al. Influence of season Biol Reprod 1986; 35: 549-53. http://dx.doi.org/10.1095/biolreprod35.3.549

[45] Stumpf TT, Day ML, Wolfe PL, et al. Feedback of 17 betaestradiol. J Anim Sci 1988; 66: 447-51.

[46] Wolfenson D, Roth Z, Meidan R. Impaired reproduction. Anim Reprod Sci 2000; 60-61: 535-47. http://dx.doi.org/10.1016/S0378-4320(00)00102-0

[47] Schams D, Hofer F, Schallenberger E, Hartl M, Karg $H$. Pattern of luteinizing hormone. Theriogenology 1974; 1: 13751 